\title{
Working Paper 07-13
}

\section{Transfers from Migrants to their Children}

Evidence that Altruism AND Cultural FaCtors MatTer

FRANÇOIS-CHARLES WOLFF

DEPARTMENT OF ECONOMICS

UNIVERSITÉ DE NANTES

SEYMOUR SPILERMAN

DEPARTMENT OF SOCIOLOGY

COLUMBIA UNIVERSITY

\section{CLAUDINE ATTIAS-DONFUT}

RESEARCH DEPARTMENT

Caisse National D’Assurance VieILlesse

Columbia University IN THE City OF NEW YORK

DECEMBER 2007 


\title{
TRANSFERS FROM MIGRANTS TO THEIR CHILDREN" Evidence that Altruism and Cultural Factors Matter
}

\author{
François-Charles Wolff \\ Department of Economics \\ Université de Nantes \\ Seymour Spilerman ${ }^{* *}$ \\ Department of Sociology \\ Columbia University \\ Claudine Attias-Donfut \\ Research Department \\ Caisse National d'Assurance Vieillesse
}

First revision, Review of Income and Wealth

February 2007

\section{ISERP Working Paper 07-13}

December 2007

\footnotetext{
\# We are indebted to two anonymous referees and to the editor for helpful comments on a previous draft. We would like to thank Agnès Gramain, Catherine Sofer, Lionel Prouteau and numerous participants at the Legos seminar (Dauphine University, Paris), the LEN seminar (Nantes University), the 22èmes Journées de Microéconomie Appliquée (Hammamet, Tunisia) and the $19^{\text {th }}$ Annual Conference of the European Society for Population Economics (Paris). We also acknowledge support from Ford Foundation grant \# 1040-1239. The usual disclaimer applies.

* Corresponding author. LEN, Faculté des Sciences Économiques, Université de Nantes, BP 52231 Chemin de la Censive du Tertre, 44322 Nantes Cedex 3, France; CNAV and INED, Paris, France. Tel: 33240141742. E-mail : wolff@sc-eco.univ-nantes.fr http://www.sc-eco.univ-nantes.fr/_fcwolff

"Center for the Study of Wealth and Inequality, Columbia University, New York.

E-mail : ss50@columbia.edu

Direction des Recherches, CNAV, Paris, France.

E-mail: claudine.attias-donfut@cnav.fr
} 


\begin{abstract}
This paper focuses on the determinants of financial inter vivos transfers by migrants living in France in 2003 to their adult children. From a theoretical viewpoint, such transfers may be explained either by altruism or by exchange. While parents would direct their assistance to their less well off children under altruism, support should be channeled to children who live nearby their parents under the exchange motive. We assess the relevance of these two motives using the French PRI survey. Unequal sharing is frequently observed and children are more likely to receive financial transfers when they are in poor circumstance, but not necessarily when living in proximity to parents. We also emphasize the role of cultural factors as determinants of the parental allocation among children. Muslim parents, in particular, are more likely to make transfers to sons than to daughters.
\end{abstract}

Keywords: altruism, exchange, inter vivos transfers, unequal sharing

JEL Classification: D62, J2 


\section{Introduction}

This paper examines how family resources are redistributed across generations by investigating parental motives in the transfer process. Drawing on a sample of foreign-born parents living in France and focusing on inter vivos cash gifts made to adult children, we give particular attention to cultural factors, especially country of origin and religion, as determinants of the allocation among children. Understanding the motives for private transfers has long been a matter of concern among economists as it relates to the effectiveness of public transfer programs.

Since inter vivos transfers have a strong impact on the attainments and living standards of adult children ${ }^{1}$, it is important to understand how parents make transfer decisions and especially how they decide on allocations among children when there are several offspring. Do parents make allocation decisions, for example, with the intention of reducing inequality among offspring (favoring a needy child) or is more given to the child who can most productively use the additional resources? Parents might make transfer decisions with their own welfare in mind or might follow cultural norms in their distributions, possibly giving larger sums to male offspring or to a first born child. Injunctions fostering the latter sorts of allocations, especially in regard to bequests, are found in the biblical texts of many faiths ${ }^{2}$ and might well guide parental behavior in traditional settings with respect to inter vivos transfers as well.

The issue of transfer allocations among children has received considerable attention by economists. The parental motives literature mainly focuses on altruism versus exchange as competing models (see Laferrère and Wolff, 2006). In essence, altruistic parents care about offspring and provide financial support to enhance their well-being. Under an exchange motive, parents make financial transfers in return for services provided by children or to indebt the children to provide services at a later time point (Cox, 1987). Exchange models are largely neutral in their consequences for the replication of inequality, while altruistic motives can reduce the effectiveness of government transfer programs because of the potential for "crowding out" private family assistance (Cox and Jakubson, 1995, Schoeni, 2002).

The considerable empirical research on altruism versus exchange motives has yielded conflicting assessments. Much of the existing literature is characterized by an assumption that one or the other of the presumed motives describes the decision making of all parents, though a few studies have sought to associate their conclusions with a particular country, recognizing the possible impact of cultural norms and local institutional arrangements (Hayashi, 1995, Lucas and Stark, 1985, Spilerman and Elmelech, 2003). To the best of our knowledge, no study has sought to ascertain whether multiple motives might be operative within a country and whether different parental designs should be associated with particular population groups in a society ${ }^{3}$.

The intent of our contribution is to assess the relevance of the altruistic and exchange models using a unique data set from France that permits both a test of the applicability of one or the other of the motives to the full population under consideration, as well as an exploration of

\footnotetext{
${ }^{1}$ Some important studies of the effects of parental transfers are Mayer and Engelhard (1996) on the waiting time to homeownership, Spilerman (2004) on the living standards of young couples, and Lindh and Ohlsson (1998) on the rate of entry into self-employment and entrepreneurship.

${ }^{2}$ The rules of inheritance in the Old Testament are outlined in Numbers 27:1-11, and Deuteronomy 21:17. In particular, a daughter can inherit only if there is no male heir. Also, the eldest son receives a double share. Christian practice has been more diverse, in some places following the biblical rule while in other European lands primogeniture was the norm. Islamic law is more complex in regard to inheritances, with detailed prescriptions for different categories of inheritors; also, in practice, inheritance patterns often differ between Suni and Shi'i adherents. In a situation in which there is a daughter and son as survivors, the son inherits a $2 / 3$ share, the daughter a $1 / 3$ share (Radford, 2000).
}

\footnotetext{
${ }^{3}$ Laitner (1997, p. 234), in a theoretical analysis, does note that "in practice, the two [motives] may often accompany one another, with altruism reducing enforcement difficulties in interfamily exchanges". Also see the discussion in Light and McGarry (2004) who focus on the planned division of estates.
} 
whether the transfer pattern differs by cultural group. The data set we use is entitled "Passage à la Retraite des Immigrés" (PRI hereafter), collected in 2002-2003, which surveyed immigrants to France regarding their financial situation, family relationships, and transfer histories (both to relatives living in France and remittances to the origin countries).

Although the data are cross-sectional, they offer several interesting features when focusing on the motives for private transfers to children. First, there are questions about the provision of transfers made during the last five years, with parents indicating whether or not they have helped each of their children. Second, parents provide information on the main characteristics of their children. This permits a reduction in measurement error, assuming the response bias is similar for all children in a family, as well as an opportunity to control for unobserved heterogeneity using random and fixed effects models. Although the income level of the children is unknown, the survey includes a measure of each child's financial circumstance. Third, the sample consists of respondents who are heterogeneous in background, in that the migrants mainly come from Southern Europe or from North African countries, with different religions and cultural traditions.

Combining these various facets of the data permit estimates that take into account unobserved heterogeneity at the family level, and enable a consideration of the role of cultural factors. Our main results are that transfers from migrants are mainly altruistically motivated, but that they are heavily influenced by the donor's religion and culture. We develop these themes in the following sections. In section 2, we briefly summarize the parental motives literature. Section 3 provides a description of the data and of the transfer patterns. Results from our econometric analysis pertaining to parental motive are reported in section 4, and the role of cultural factors in the transmission process is addressed in section 5.

\section{Motives for private transfers: A brief review}

Economists have suggested two main hypotheses to explain the motives behind private transfers, i.e. altruism and exchange (Laitner, 1997, Laferrère and Wolff, 2006).

Let us first consider the altruistic scenario, according to which parents care about their children's situation (Becker, 1974). Assuming that parental income is sufficiently high to permit the transfer of financial resources, parents maximize a weighted sum of their own level of satisfaction and their children's levels of satisfaction. Transfers are then a means to redistribute money across generations and among siblings. When parents help their children, individual levels of consumption (either of the parent or the children) do not depend on the distribution among the various family members. This income pooling property is the basis of the well-known Rotten Kid theorem (Becker, 1974).

In an altruistic setting, parents will increase the transfer amount when their own income has grown. Despite the loss in their private consumption, parents will be more than compensated by the rise in the children's well-being. Conversely, for a child, the amount of transfer received is lower when the child is richer. Parents are also expected to favor those children who are in a poor situation relative to their siblings. Consider, for example, a sibship with two children, a rich one and a poor one. If the rich child receives extra revenue, parents will reduce the gift value made to the rich child. The additional amount of "saved" resources may then be transferred to the other, poorer child. So, the shape of parental transfers fully depends on the distribution of incomes between the various family members ${ }^{4}$.

Unequal transfers between siblings are expected under altruism. Nevertheless, equal sharing could be observed in the particular case where children are characterized by differentiated revenues, but parents are more altruistic towards a child who, say, "performs better" in some arena

\footnotetext{
${ }^{4}$ A redistribution of resources between the parent and one child leads to a perfect adjustment in the transfer value, family income being held constant (see the discussion in Altonji et al, 1997).
} 
of interest to the parent. Other explanations may be invoked for equal sharing within the family. Wilhelm (1996) argues that parents may suffer a psychic cost if they deviate from an equal allocation of resources. Stark (1998) suggests that a child who receives less than his or her siblings may feel under-appreciated, so that parents perceive emotional costs to treating their children differently.

The exchange motive involves some reciprocity between generations. Cox (1987) and Cox and Rank (1992) claim that financial gifts made by parents constitute payment for services and visits provided by children. Another mechanism is the familial loan model, where parents lend money for consumption, to be repaid in the future with a presumably above-market interest rate (Cox, 1990). In contrast with the altruistic model, the relationship between the amount of transfer received and the child's income may be either positive or negative, depending on the elasticities of supply and demand for time-related resources. As a child becomes richer, parents have to pay a higher price if they want to obtain the same amount of services from that child, but they may also purchase a lower level of attention 5 .

The exchange model leads to other interesting consequences. First, money-service exchanges are likely to generate an unequal division of transfers within the family. As pointed out in Cox (1996, p. 84), some children may have a comparative advantage to specialize in the provision of time-related resources. This would be the case, for instance, for children who do not have a paid job or who live in shared residence arrangements or nearby their parents. Second, a positive relationship between the measure of services and the financial transfer is expected (Cox and Rank, 1992). Nonetheless, such a pattern may also be consistent with two-sided altruism as in Becker and Murphy (1988).

Testing the relevance of the altruistic and exchange models should then be conducted at an intra-household level, with an emphasis on the allocation of private financial transfers among siblings. Surprisingly, many empirical analyses investigate transfers that are received by only one focal child in a family. This approach is certainly less data demanding, but it conveys much less information about the parental intent. A few papers have examined how parents divide their resources among children. These studies all reach a similar conclusion for inter vivos transfers, namely that poor children are more likely to be helped by their parents.

Drawing on the Health and Retirement Survey and using fixed effects models, McGarry and Schoeni (1995) find that respondents give greater financial assistance to less well off children than to offspring with higher incomes. In a second study (McGarry and Schoeni 1997) they also conclude that transfers mainly benefit poorer children within a family, and they reject the thesis that parents provide financial help in exchange for caregiving. Hochguertel and Ohlsson (2003) report that only $5 \%$ of parents in the US who give money to their children divide the gifts equally among the offspring. There is also evidence that parents use inter vivos gifts to smooth the income of their children, providing assistance at times when the child's resources are below his or her permanent income (Dunn, 1997, Dunn and Phillips, 1997).

In France, there has not been an empirical investigation of the intra-household allocation of parental resources. We attempt to fill this gap by examining a new survey of migrants living in France which contains detailed information on inter vivos transfers between parents and offspring. While our results are not representative of the full French population, an analysis of migrants relates to the behaviors of a growing segment of the population in this country, as well as in much of Western Europe. Further, because of the diverse backgrounds of the respondents we are able to inquire about the residual impact of origin country and culture, which may well influence intrahousehold transfer decisions.

\footnotetext{
${ }^{5}$ If there exist only poor substitutes for the child's attention (Cox, 1996), then the relationship between the child's level of resources and the amount transferred by the parent should be positive.
} 


\section{Data and descriptive statistics}

\subsection{The PRI Survey}

The 'Passage à la Retraite des Immigrés', used in the empirical analysis, is a cross-sectional data set collected in France between December 2002 and March 2003 by the Caisse Nationale d'Assurance Vieillesse, in collaboration with the Institut National de la Statistique et des Etudes Economiques. The primary focus of the survey was to provide an accurate description of the wayof-life of migrants currently living in France, especially with respect to migration history and their retirement and location expectations.

With the aging of migrants, it is important for policy makers to know whether they intend to stay in France or return to their origin countries. As the aim of the survey is to better understand their retirement decisions, the sample comprises 6211 individuals between 45 and 70 years of age ${ }^{7}$. Each respondent was asked not only about his or her own situation, but also about the characteristics of other family members. A central feature of the survey is that it contains information on transfers given to all children and, hence, permits an examination of the intrahousehold distribution of financial assistance. Furthermore, given the life-cycle stage of the migrants, most of their children are adults, many at points in which they have substantial financial needs (such as for the purchase of housing or to start a family).

In this paper, we restrict attention to financial transfers given by parents to their children. Our primary focus is not one of understanding how intergenerational transfers flow within foreign-born families, whether upwards or downwards (see Attias-Donfut et al, 2006b), but one of investigating the intra-household allocation of parental assistance. The parent is the respondent in the survey. For each respondent, information was collected on gender, age, matrimonial status (living as a couple or not), numbers of children at home and elsewhere, years of education, selfreported health status, occupational situation, household income, and religion. The survey also includes a description of the migration history of the respondent: origin country, duration in France, and whether or not French citizenship is held.

Concerning the children's characteristics, information was collected from the parent about each child, whether living in the parental home or elsewhere. This is an important feature of our data, since it permits some insight into parental allocation preferences. For each child, we have information on gender, age, citizenship, distance from the parental home, and contacts and visits with parents. In addition, for offspring older than 16, there are questions about the child's economic situation. Although we lack data about the child's income, the survey provides several variables by which we can proxy household income and material need.

In addition to educational attainment, we know whether the child is currently a student, unemployed, otherwise not in the labor force, or employed. For the last category, we have information about whether the job is performed in the private sector, in the public sector, or as self-employment. There is also a subjective question concerning the child's level of financial wellbeing, given by an ordinal scale (ranging from 'very poor' to 'financially very comfortable'). This subjective information is a-priori strongly correlated with the child's level of income, though there may be measurement error and endogeneity concerns as a result of a self-serving response bias. These issues are addressed in the empirical analysis.

\footnotetext{
${ }^{6}$ For a detailed description of the survey, see Attias-Donfut et al (2006b). While the data are not yet in the public domain, an English language version of the questionnaire can be obtained from the authors.

When designing the sample, exactly 12,010 migrant households living in France were randomly selected from the Census. The questionnaire was completed for 7,433 households, while there was no answer in 4,577 cases (refusal, impossible to contact, absent, etc). Finally, 1,222 cases were dropped from the sample, because the respondent did not meet either the age or the migrant criterion. Thus, 6,211 questionnaires are available to researchers. The questionnaire required approximately one hour to administer.
} 
We now describe the sample selected for the study. First, trivially, we restrict attention to parents having children. Second, we only focus on adult children. These offspring are defined as being at least 20 years old at the time of the survey. Third, we account for children residing either in France or in the origin country. Fourth, we delete the few cases $(\mathrm{N}=95)$ with missing data on either parental or children's characteristics. Finally, since we want to investigate transfer decisions at the family level, we construct a new sample where each child is counted as one observation. Thus, a parent who has three adult children will contribute three observations to the new sample.

Owing to the various selections, the sample we constructed contains 13,762 child-parent pairs, corresponding to 4,999 families ${ }^{8}$. The key feature of this sample is that it provides information on how parental characteristics influence the decision to assist adult offspring. With these data we can assess the possible tendency by parents to provide more assistance to a child with particular characteristics. However, the children from the same parental household are not independent observations; as a consequence, an appropriate correction method using panel data techniques is needed when performing regressions.

Descriptive statistics are reported in Table 1. Referring, at this point, to the total sample (column 7), the mean age of the parents is 58 years, and $83.5 \%$ of them are living with a partner. They have completed 6 years of education on average, and $47.4 \%$ are home owners. Concerning migration history, the mean number of years in France is around 34. Approximately one-third hold French citizenship and 50.1\% have difficulty with reading French. There are significant differences in cultural background. Some 42\% come from Europe and 47.5\% from Africa. Moreover, these continent groupings are concentrated in a few countries, with six nationalities representing around $75 \%$ of observations. Among European migrants, 34.3\% are from Portugal, Italy and Spain; among African migrants, $42.8 \%$ come from Algeria, Morocco and Tunisia.

\section{Insert Table 1 here}

Regarding the children, $49.1 \%$ are girls and the mean age of the children is 30 years. They have more schooling than their parents, with 11 years of completed study, versus a parental average of 6 years. We note that $64.7 \%$ of the children are employed, $12 \%$ are students, and $10 \%$ are unemployed. Parents most often consider their children to be in a fair economic situation (54.2\%), but $17.3 \%$ are viewed as financially poor by their parents ${ }^{9}$. Finally, while only $12 \%$ of the children live outside France, much of the cross-generation monetary flow returns to the origin country. In this respect, the latter transfers are closely related to remittances. Given these data features, it is necessary to take into account the possibility of heterogeneity, both between and within families, owing to the effects of location and cultural tastes.

\subsection{The pattern of financial transfers}

The exact question in the survey concerning private transfers is: "During the past five years, have you provided money, either regularly or occasionally, to family members or friends?" If yes, the respondent is asked to provide detailed information about each transfer. Importantly, at most four transfers are recorded in the survey. When some money is given to a child, we know which child received the assistance. Also, for each gift, there is information about the parental motive. The respondent had to choose between several alternatives, like helping the child because

\footnotetext{
${ }^{8}$ Among the 6,211 respondents, exactly 430 have no children and were excluded from the sample. From the remaining families we obtain 19,285 children. Since we focus on children aged 20 and older, our final sample comprises 13,762 parent-child pairs.

${ }^{9}$ Where parents were not aware of the financial circumstance of a child, the response 'unknown' was coded in the survey. Since the number of 'unknown's was relatively few, in the analysis these children were included in the intermediate 'fair' category, where they comprise less than 5\% of observations in this category. To examine the robustness of the results, we also constructed a variable with four categories for the child's financial situation (poor, fair, rich, and unknown). The estimates are very similar with the two definitions of the child's economic circumstance.
} 
of financial problems, buying a dwelling, because of a family event (e.g., marriage, birth, communion), etc. This information can be helpful in discriminating between altruism and exchange $^{10}$. Finally, we have information on the value of the gift.

A difficulty, however, is that the gift amount received by a child is coded in eleven categories. One strategy that can be used with such data is to estimate interval-level models, which allow for an observation to be either point, interval, left-censored or right-censored. A second approach is to construct a continuous distribution from the categorical data, making use of the information about interval sizes and coding each cell by its midpoint. Normally, there is a question about the value to be assigned to the highest category, which is open-ended. However, in the present survey, there were no respondents in this category, which is receipt of a transfer greater than 90,000 euros, or even in the immediately preceding category $(60,000 \text { to } 90,000 \text { euros })^{11}$.

Using this approximation we obtain a mean value of 2727 euros per transfer, with a standard deviation of 5848 euros. There is, however, a problem with this approach when the income variable is used as a dependent variable in a regression model, namely, the error distribution cannot be assumed to be normal because the measurement error in the dependent variable is non-normal ${ }^{12}$. We therefore also use a third approach, which draws on the method of simulated residuals described in Gouriéroux et al (1987). In this formulation, one constructs a continuous distribution from information on a categorical variable by inferring from a regression model a predicted value for the outcome and then adding a random term. For each observation, the 'augmented' predicted value (in the sense that it includes a random component) has to match the original category.

We applied this technique to the categorical information so that, for each positive transfer, a continuous value was obtained which consistently matches its original interval. ${ }^{13}$ The mean transfer value with the method of simulated residuals is 2613 euros, quite close to the estimate of 2727 given by the midpoint approximation, and the standard deviation is almost identical under the two estimation procedures (5808 euros with the simulated estimates). In modeling the transfer receipts, we employ all three approaches (interval, midpoint, simulated) to assess whether the substantive results are sensitive to the definition of the dependent variable.

Several points should be noted concerning the measurement of private transfers with the PRI data. First, transfer information was collected only for the last five years. This can be problematic since the transfer probability is clearly a function of the time interval referenced in the question. A longer period would surely have produced more transfers. Thus, the available data do not permit a comprehensive description of transfers over the full life course ${ }^{14}$. Offsetting this loss is the ability to better link the provision of transfers to the current situation of the recipient. Transfers that were made many years earlier cannot be easily associated with present levels of need. Past gifts may also have influenced the child's current financial status, which can lead to a causality issue.

\footnotetext{
${ }^{10}$ However, such data must be used with caution. A parent who decides to help a needy child is certainly motivated by altruistic feelings, but a transfer related to housing or school expenditures conveys little information about an altruistic or exchange intent.

${ }^{11}$ The distribution of gift amounts is quite skewed. Some $36 \%$ of observations fall in the lowest transfer category (less than 360 euros); $18 \%$ in the next lowest category (380-760 euros). From that point the fall off is roughly exponential, with $3 \%$ of observations in category 9 (15,000 to 30,000 euros), the highest category containing 0 observations.

${ }^{12}$ We would like to thank an anonymous referee for pointing out this out.

${ }^{13}$ We compute a continuous value once for each financial transfer. This generates a continuous distribution of the transfer amounts which is then used in the various regressions.

${ }^{14}$ Because of recall problems, the tendency to inquire about transfers during a limited time interval is common to many large scale surveys. Thus, the National Survey of Families and Households inquires about transfers during the prior five years, while the Health and Retirement Study asks about transfers in the preceding 12 months.
} 
Another problem is that at most four recipients are recorded in the survey. However some families with more than four children are included in the regression analysis. This could produce an overestimate of the frequency of equal transfers (that is, assistance provided to all children) were an omitted child to not have received a transfer. Fortunately, there are very few families in the PRI survey who report gifts to as many as four recipients over the five year period (a frequency of less than 1\%). As a consequence, the PRI survey, with its detailed description of the parent and with information about each potential recipient, is well suited for investigating the matter of the intrafamily allocation of transfers.

As reported in Table 1, some $9.2 \%$ of children were helped by their parents during the five years preceding the survey, a transfer rate that is low in comparison with comparable studies (e.g., McGarry and Schoeni [1995, p. S188] report a receipt rate of $13.8 \%$ in the prior 12 months in the Health and Retirement Survey). While the transfer rate in the PRI study may appear low, and the transfer amounts are small since the (simulated) mean value is 2613 euros for each receiving child, one has to keep in mind that migrants living in France have little in the way of financial resources with which to help their offspring. Further, the migrants have other family members, besides children, residing in the origin country and part of the migrant's resources is transmitted to these relatives in the form of remittances. As to the distribution of the transfer amounts, the disparities are huge since the (simulated) median is 688 euros while the mean is equal to 2613 euros. Clearly, most transfers involve small monetary sums, though a few are large enough to be viewed as serious transmissions of parental wealth.

Table 2 provides details about how the transfer stream varies by origin location and religion. The frequency of receipt, as well as transfer amount, is much higher for children of migrants from Europe and America than from the other continents. The probability for a child being helped is equal to $13.6 \%$ for European-origin families, but only $5.3 \%$ for families from Africa. Even within Europe, there exists a gap between northern and southern countries. The transfer rate is more than twice as high in the former. In part, origin country is a proxy for the level of household resources. Migration from southern countries is linked to job intentions, especially for low-skilled workers, while migration from northern countries is more often associated with reasonably well-off households seeking a better location for retirement. Another consideration relates to family size, which tends to be larger for North African migrants and which may reduce the likelihood of a transfer receipt by any one child.

\section{Insert Table 2 here}

Similar results are found with respect to the religion categories. We created six dummy variables, covering Catholic, Muslim, Protestant (including Evangeliste and Anglican), other Christian (Orthodox, Gregorian, Maronite, other Christian Armenian), no religion, and a residual "other" category which includes respondents who did not report a religious affiliation. Again, we find sizeable disparities, which can be associated with Northern and Southern countries. The probability for a child to be helped is $12.8 \%$ when the parent is Catholic, but only $4.3 \%$ when the parent is Muslim. These differences possibly reflect income disparities (Muslims immigrants come predominantly from North Africa and tend to be poorer) or cultural norms regarding intergenerational support, which, in Muslim countries, could be more oriented toward assisting elders.

A consideration of the reasons conveyed by the parent for making a transfer, reported for the full sample in column (1) of Table 3, may be helpful in determining the transfer motive, although the responses must be examined with caution. It is possible that parents declare themselves as more altruistic than they are in daily life. When examining the primary reason stated by the donor, we find $42.9 \%$ of the gifts are directed to help children because of financial problems. As noted, this is not surprising since most of the children receive transfers of limited value, too small to assist with the purchase of expensive items such as a home. 
The fact that parents help children when they are needy is consistent with some altruistic motives. Yet, a benevolent motive is insufficient for explaining what happens in the migrant population. Indeed, the data suggest that several motives may be operative. On the one hand, $13.8 \%$ of parents helped their children to buy a dwelling and $6.9 \%$ are concerned with nonhousing expenditures. On the other hand, $8.6 \%$ of the gifts have been made in response to 'happy' family events, and $15.9 \%$ of parents simply state a desire to make a gift. Clearly, the latter sorts of transfers are not associated with poor financial circumstances on the part of children. Beyond this account, there are substantial differences in motive by religion (columns (2) and (3)), a theme that we explore later in the paper.

Concluding our overview of parental decision making among migrants, we present summary statistics in Table 4 on the intra-family allocation of transfers, which will be particularly relevant to our consideration of cultural factors in the transmission process. Because of the questionnaire design, noted earlier, this sample is restricted to families with four or fewer children. Also, one child families are omitted from the calculation of equal/unequal transfers because there is no allocation decision to be made. The sample for the subsequent regression analysis of unequal versus equal allocation is therefore reduced to 3,149 families.

\section{Insert Table 4 about here}

Consider the magnitude of unequal sharing and, for the moment, examine only the top panel, referring to the total population. On average, some money is received by all the children, our definition of equal sharing, in $7.9 \%$ of cases (column 4) while the proportion of families in which at least one child, but not all, obtained parental assistance is $9.8 \%$. Hence, among families that received assistance, the frequency of unequal sharing is $55.4 \%$, a figure only slightly below the reports of others (e.g., Wilhelm 1996, though with respect to bequests). Not unexpectedly, the odds of unequal sharing increases sharply with family size (column 5).

We emphasize that our characterization of "equal" and "unequal" sharing is based on transfer probabilities, not on amounts transmitted, and is therefore an approximation to the true figures. The frequency of unequal sharing is overstated because of the different ages of children in a family and the limitation of the observation period to the last five years. Any transfer made outside this time interval is not visible to us. On the other hand, the rate of unequal transfers may be understated because we make no reference to amounts, only to whether a transfer was received by a child ${ }^{15}$.

\section{Econometric Analysis of the Determinants of Transfers}

To understand transfer decisions within the migrant population, we undertake an econometric analysis using the matched child-parent sample. The dependent variable is a dummy term which is equal to one when some money is received by a given child. The regressors are the usual human capital and demographic characteristics of the parent plus terms for health status, household income, homeownership, and three variables that relate to the migration trajectory of the respondent (duration in France, whether or not French citizenship is held, and whether the migrant experiences problems in reading French). To capture possible cultural effects, we introduce a dummy term for the Muslim religion. We also introduce a set of variables that tap characteristics of the child.

As we have repeated information on children for many of the families, standard regressions such as Probit models will produce biased estimates. As pointed out by McGarry and Schoeni (1995), unobserved factors associated with transfers, such as the extent of parental altruism or the taste for redistributing resources, tend to be correlated among siblings. We therefore account for

\footnotetext{
${ }^{15}$ We also constructed an alternate definition for equal transfers, based on amounts in the range of 0.9 to 1.1 of the average for the sibship during the preceding five years. The multivariate results are quite similar under the two definitions.
} 
family unobserved heterogeneity through the use of panel data techniques. Either a random or fixed effect formulation permits the potential bias induced by the presence of unobserved parental characteristics to be controlled for, and we consider both formulations in order to assess the sensitivity of the results to method. We begin by estimating a random effects Probit model. With this specification, it is assumed that the explanatory variables are uncorrelated with the unobserved parental effects.

The results are reported in column 1 of Table 5. Regarding the consequence of parental characteristics, the probability of a child receiving assistance increases with parental age until 56.4 years and then declines, possibly a consequence of the greater need for funds as retirement is approached. We also observe a fall off in the probability of receipt as a function of the number of children in the parental household, irrespective of whether they live at home or elsewhere. This suggests a process of competition for parental resources--the more siblings, the lower the probability of receiving assistance. Not surprisingly, the gift rate is a positive function of education, income, and homeownership, as each of these terms taps the financial status of the parent. We also find evidence of an acculturation effect, in that difficulty with reading French by the parental respondent, net of controls for human capital and other parental resources, reduces the likelihood of receipt by a child, a suggestion of the continued impact of country of origin and the norms thereof among the less integrated migrants. Similarly, there is an indication of a religious predisposition, in that the transfer rate is lower among Muslim respondents, though this result is only marginally significant.

\section{Insert Table 5 here}

Characteristics of the child also contribute to the receipt incidence. Indeed, an assumption of insignificance of the child's covariates in the Probit equation is rejected by a Wald test; clearly, parents take into account the needs of their children in making transfer decisions ${ }^{16}$. The likelihood of receipt of assistance is an increasing function of a child's age until 36 years; beyond this point assistance from parents becomes less frequent. It is hardly surprising that parents target transfers to younger offspring who, presumably, are coping with the costs of starting a household or with childrearing. A result of some interest relates to gender: female children are substantially less likely to receive transfers than their brothers. Interestingly, this result departs from studies in the United States (e.g., McGarry and Schoeni, 1995).

The direct measures of the economic circumstance of a child provide the clearest insight into how parents make transfer decisions. The child's economic situation is proxied by a set of variables: education, occupation, and a subjective measure of financial need that was reported by the parent. While the education variable is not significant, both occupational status and the financial terms provide consistent results: assistance is more likely to be received by a child who is a student or otherwise not in the labor force, in contrast with one who is employed. Further, parental aid is more frequent if a child is in fair or poor financial circumstance, rather than "rich". Migrants to France, clearly, target their less well-off children for transfers ${ }^{17}$.

To investigate the sensitivity of the results to our correction for unobserved heterogeneity, we utilize the conditional (fixed effects) Logit approach described by Chamberlain (1980). The sample is now restricted to families in which at least one child but not all received a transfer. Parental characteristics are not introduced since they do not vary among the children of a given sibship $^{18}$. With this restriction the number of observations is reduced to 1,449 . Estimates for this

\footnotetext{
${ }^{16}$ This suggests that in the migrant population we can reject the hypothesis that transfers from parents are explained by some kind of warm-glow process, according to which parents derive egoistical pleasure from the act of giving.

${ }^{17}$ Cox (1990) suggests that the negative relationship between the probability of transfer receipt and the recipient's economic situation may be a consequence of liquidity constraints.

${ }^{18}$ Both observed and unobserved parental characteristics are, of course, picked up by the family fixed effects.
} 
fixed effects model are reported in column 2, and show results that are consistent with the random effects specification. We find, again, that children not in the labor force, and offspring in fair or poor financial circumstance, are more likely to obtain assistance. Again, we note that the likelihood of receipt increases with distance from the parental home and that female children are less likely to receive support.

A related matter concerns the reliability of the parent's assessment of a child's financial situation. This could raise an endogeneity issue in that parents might report a child to whom a transfer has just been given to be in poor financial circumstance, i.e. essentially an attempt by the parent to achieve cognitive consistency ${ }^{19}$. However, the parent is the source of information about all the children in a household. We therefore assume that measurement error contained in the parental report is the same for all the offspring, in which case much of the bias would be removed in the fixed effects formulation ${ }^{20}$. However, this condition is unlikely to hold to the extent that the measurement error depends on the amount of time elapsed since the transfer was given, or on the amount of the transfer.

We attempt to explain the transfer amount received by a child using a Tobit model with a random effects specification to control for unobserved heterogeneity at the family level (columns 3 and 4 of Table 5). We estimated the model twice, once with the amount given by the midpoints of the receipt categories, and a second time with the simulated transfer distribution. We obtain similar results from the two formulations, suggesting that our findings are robust to the coding of the dependent variable. As in the analysis of the incidence of receipt, we conclude that financially well to do parents provide more funds to their children, that a smaller sibship size means a larger transmission, that lack of acculturation (difficulty with reading French) reduces the transfer amount, and that smaller sums are received by children of Muslim migrants. Similarly, in regard to the children's characteristics, we find a preference in the amount transferred for offspring who are in fair or poor circumstance, who live in the origin country or in France but at a distance from the parent, and who are male; in short, findings that are analogous to the determinants of transfer incidence.

To further assess the sensitivity of the results to the coding of the dependent variable, the preceding analysis was replicated using an interval regression model with the zero values treated as point data and the positive amounts as interval data. The estimates from this specification (column 5) are quite similar to those of the Tobit regressions. There are a few differences with the children's covariates, especially "female" and "not in labor force" which are now insignificant; however, the parental transfers clearly remain targeted towards the poorer children.

To summarize, this analysis of migrants to France suggests that parents are more likely to help their poorer children, a finding that is consistent with both an altruistic and an exchange motive. A further finding, however, supports altruism. The exchange motive is based on a notion of reciprocity, such as transfers given to a child in return for assistance to parents in the form of visits and other services. Such a process would suggest more frequent or larger transfers to children who live in proximity to parents and, consequently, are in a better position to provide services. In this regard, the findings in Table 5 consistently indicate a positive effect of distance within France

\footnotetext{
${ }^{19}$ We stress that the same problem pervades many studies of the distribution of private transfers within the family. In many questionnaires, the parent is asked about the financial situation of the children. Even when the parent chooses among different income categories, the parent may be tempted to understate the true income of a child if a transfer has just been given to the child.

${ }^{20}$ We re-estimated the various models excluding the parental measure of the child's financial situation in order to assess the extent of change in the coefficients of the more objective measures of financial need. The findings, not reported here, show that the preference for less well-off children is a robust finding. Indeed, with the fixed-effect Logit specification, the probability of a child receiving a transfer is higher when the child is a student or otherwise not in the labor force. Also, the coefficient attached to the unemployment term becomes significant at the one-percent level, though it barely reaches significance in the regressions in Table 5, which include the parental subjective estimate of child's financial status.
} 
on both transfer frequency and amount, and a higher rate of transfers to children living outside of France, findings that are inconsistent with an exchange motive.

\section{Cultural influences on the parental allocation}

Migrants bring with them a cultural heritage regarding appropriate family arrangements and the responsibilities of parents and children toward one-another. Although the full force of these traditions is likely to be eroded with duration in the receiving country, immigrant groups that are very different from long term residents in language, religion, and normative values are likely to acculturate slowly (Breton, 1964).

In this section, we examine the Muslim versus non-Muslim divide among migrants to France because this division represents a deep cleavage in French society and elsewhere in Europe. Some evidence of the force of this distinction for parental transmissions is apparent in the descriptive information of Table 3. From the entries in columns (2) and (3), it is evident that there are rather considerable differences among the communities in reasons for providing assistance to children. Whereas 35\% of non-Muslim parents emphasize the financial need of children, the entry for Muslims is more than twice this figure. In part, the disparity might reflect the differential financial needs of children in the two communities, or differences in economic resources among the migrants, matters that we explore in this section.

To make evident the dimensions of the cultural differences, we report in Table 4, panels B and $\mathrm{C}$, the differential tendency toward equal allocation on the part of the two migrant communities. Overall, the rate of assistance to children is twice as high among non-Muslims $(21 \%$ versus $10 \%$, see total figures in column (2)), but this might also be due to the lesser resources of Muslim parents. More compelling is the huge disparity between the communities in tendency toward equal allocation, $10.4 \%$ among non-Muslims, 1.5\% among Muslims (column 4). This proclivity is summarized in column (5) which reports the ratio of unequal to equal allocations, revealing a massive difference between the groups. Further, a Probit model for unequal versus equal sharing which uses parents as observations (column 6 of Table 5), makes clear that controls for parental resources do not eliminate the tendency toward unequal sharing in the Muslim population. Indeed, there is little indication that the level of parental resources, as measured by income or wealth (homeownership), influences the parental decision, though there is a small tendency toward equal allocation among better educated respondents.

With this motivation for examining cultural effects, we turn to a more detailed examination of the allocation process. Probit estimates for the probability of a transfer receipt, by religious community, are reported in columns (1) and (4) of Table 6 . What is apparent is the much greater responsiveness by non-Muslims to the parental characteristics, as measured by the magnitude of the coefficients. For this religious/cultural group transfer receipt reflects parental age, peaking at 61 years, education, and household income (see Figure 1). These variables have less impact on decision making among Muslim parents. Also, the numbers of children at home and the number outside the home--measures of competition for parental resources that are significant for both communities--show greater effects for non-Muslims. With respect to the number of children at home, the marginal effect is almost ten times as large among non-Muslims than among Muslims: an additional child reduces the receipt probability by 3.7 and 0.38 percentage points, respectively.

\section{Table 6 and Figure 1 about here}

With one notable exception, the consequences of the children's characteristics for receipt of a transfer are less dramatic. In both communities the less well off child is more prone to obtain assistance; similarly, in both, the likelihood of a transfer receipt is greater for a child residing outside France, though the effect is considerably larger for Muslim migrants. What is distinctly different, however, is the role of gender in the two communities. A Muslim daughter has a receipt 
probability that is around $40 \%$ of a son's value (estimated at the means of the explanatory variables); among non-Muslims there is no gender difference.

We suggest that the gender effect is a cultural artifact. As remarked earlier, in note 2, it is prescriptive in Muslim societies to provide smaller bequests to daughters; this norm may well influence inter vivos transfers as well. Further, in clan organized societies such as the Arab and North African countries, parents often see their adult daughters as belonging to the husband's family upon marriage, and may consider them to have a lesser claim on the resources of the birth parents (Jowett 1991).

To pursue the matter of the robustness of the estimates in the context of unobserved parental characteristics, we report in columns (2) and (5) the results from a fixed effects Logit model. For reasons discussed earlier, these regressions are restricted to the subsample of children from sibships of size two to four. The results are similar to those from the random effects models. In both communities there is a tendency to provide more support to a needy child, to prefer the child who does not live in France or who resides at a greater distance from the parental home. The most noteworthy difference is that with the fixed effects model we find a lower rate of transfer receipt by daughters of non-Muslim migrants relative to the sons, though the gender disparity is much greater in the Muslim community. In the former, the preference for sons translates into a receipt rate for daughters that is $69 \%$ of the son's rate, whereas, among Muslims, the corresponding figure is $36 \%$.

In regard to transfer amount, the findings parallel the results for the incidence analysis (Tobit model, columns (3) and (6) of Table 6). With respect the parental characteristics, one difference is that, among non-Muslims, we find a stronger effect of financial resources, in that home ownership (an indicator of equity) is now significant. With respect to the child's characteristics, two matters stand out. First, there is a reversal between the Muslim and nonMuslim groups with respect to the importance of the parent's and child's characteristics, as judged by the magnitudes of the coefficients. The parental terms have larger effects among non-Muslims whereas the child's characteristics exhibit greater impacts among Muslims. Second, in contrast with the (fixed effects) incidence analysis, there now is no evidence of a disadvantage for daughters among non-Muslims, while their disadvantage in the Muslim community remains substantial.

To summarize, parental characteristics and especially the financial resources of parents appear to be less relevant to transfer decisions by Muslim migrants. In the main, the pattern of transfers by this group reflects measures of their children's financial need, rather than differences in the availability of parental resources. This can be interpreted as suggesting a more calculative approach by Muslim parents in making transmittal decisions. Funds in some amount are routinely provided when required by a child, irrespective of the parents' financial circumstance. The data in Table 3 are consistent with this assessment: Muslim parents provide assistance "because of financial need" at a rate that is twice the figure for non-Muslims. At the same time, as befits parents who often are poor, the amounts provided tend to be quite small (compare columns 2 and 3 of Table 3). The second distinctive difference between the religious/cultural groups relates to the children's characteristics. While parents from both communities are responsive to the financial needs of their children, daughters are singled out by Muslim parents for substantially fewer transfers and lesser amounts.

\section{Concluding comments}

The objectives of this paper were twofold: to compare the contrasting motives for parental transfers, altruism versus exchange, in a population of migrants to France, and investigate the role of cultural values, centered upon family relations and deriving from religious beliefs, on intergenerational transfer decisions. In the full population sample the results of our analysis provide support for the altruism thesis, in that the more needy children in a family have a higher probability of receiving assistance and, more critically, transfers do not diminish with distance 
from the parental home. To the contrary, children living far from their parents or residing in the origin country appear to have a higher incidence of receipt and acquire greater sums.

When we separate the migrants by religion, a rough proxy for cultural background, we find support for an altruistic motive in each of the groups. In both there is a greater likelihood of assistance being received by needy children, and in both the critical test variable, distance from the parental home, continues to refute an argument that children who live in proximity to their parents are more likely to receive assistance. The last finding detracts from an exchange motive account, which would tie transfer receipts to services provided to parents, as this would suggest greater assistance given to children who live close to the parental residence. Our empirical results therefore differ from Arrondel and Laferrere (2001) and Wolff (2000), who report larger transfers to financially better-off children, though they are consistent with McGarry and Schoeni (1995, 1997) and Dunn and Phillips (1997). Beyond these findings we note rather distinctive cultural effects that influence transfer behavior, i.e. the lesser importance of parental resources in the decision process of Muslim migrants, the larger tendency in this community to differentiate among children and, as part of this calculation, the tendency to favor sons over daughters in the allocation decision.

We hasten to point out that while our results favor altruism over exchange as the dominant parental motive, our data do not permit a test of the neutrality property of the altruistic model, as in Altonji et al (1997). ${ }^{21}$ Also, there are some exchange models that cannot be tested with the sort of data available to us, such as ones that postulates (or postulate ??) a lag between the financial assistance provided to children and the services required by parents. Thus, if the migrants intend to return to their origin countries in retirement (as some do) and plan to reside nearby the children currently living there, or if the respondents calculate that there is a greater likelihood of receiving services in the future from less well off children because their time costs are lower, these kinds of exchange models cannot by rejected by our findings. What we can say is that our results do not support models of contemporaneous reciprocity between parents and children as guiding parental transfer decisions.

As a final matter, we return to the importance of culture in assessing parental motives. While our conclusion from this study, based principally on the analysis of receipts by the several children in a parental household, is that a single parental motive (altruism in that case) characterizes the transfer behavior of both Muslim and non-Muslim parents, this should not be assumed to hold true across societies. There is prima facia evidence, for example, that in less developed countries children are valued for the services they can bring to the parental home and, indeed, even conceived with such ends in mind (De Voss, 1985).

One reason why sibships are large in less developed countries is that children are necessary to help farm the land, bring income to the household, and otherwise assist with the maintenance of a small family enterprise (Clay and Johnson, 1992). In the same vein, in these countries, children are often regarded by parents as representing assurances that they will be cared for in their later years (Jowett, 1991, Lillard and Willis, 1997). Such expectations are even articulated by parents, so it would not be surprising if these considerations were to enter into their calculations when contemplating transfers to offspring.

\footnotetext{
${ }^{21}$ Under an altruistic motive, a euro increase in parental income together with a euro decline in a child's income should be offset by the transfer of one euro from the parent to the child. As shown in Wolff (2000), this property is strongly rejected in France.
} 


\section{References}

Altonji J.G., Hayashi F., Kotlikoff L.J., (1997), "Parental altruism and inter vivos transfers: Theory and evidence", Journal of Political Economy, vol. 105, pp. 1121-66.

Attias-Donfut C., Daveau P., Gallou R., Rozenkier A., Wolff F.C., (2006), L'enracinement. Enquête sur le vieillissement des immigrés en France, Armand Colin, Paris.

Attias-Donfut C., Wolff F.C., Tessier P., (2006), 'Les transferts intergénérationnels des migrants âgés', Economie et Statistique, n 390, pp. 3-23.

Becker G.S., (1974), “A theory of social interactions", Journal of Political Economy, vol. 82, pp. 1063-1093.

Becker G.S., Murphy K.M., (1988), "The family and the State", Journal of Law and Economics, vol. 31, pp. 1-18.

Breton R. (1964), "Institutional completeness of ethnic communities and the personal relations of immigrants", American Journal of Sociology, vol. 70, pp. 193-205.

Clay D.C., (1992), "Size of farm or size of family: Which comes first?” Population Studies, vol. 46, pp. 491-505.

Cox D., (1987), "Motives for private income transfers", Journal of Political Economy, vol. 95, pp. 508-46.

Cox D., (1990), "Intergenerational transfers and liquidity constraints", Quarterly Journal of Economics, vol. 104, pp. 187-218.

Cox D., (1996), “Comment on James Davies: Explaining intergenerational transfers”, in Menchik P.L., ed., Household and Family Economics, Kluwer Academic, Boston, pp. 83-90.

Cox D., Jakubson G., (1995), “The connection between public transfers and private interfamily transfers", Journal of Public Economics, vol. 57, pp. 129-167.

Cox D., Rank M.R. (1992), "Inter vivos transfers and intergenerational exchange", Review of Economics and Statistics, vol. 74, pp. 305-314.

De Vos, S., (1985), "An old-age security incentive for children in the Philippines and Taiwan," Economic Development and Cultural Change, vol. 33 (4), pp. 793-814.

Dunn T.A., (1997), "The distribution of intergenerational income transfers across and within families", Mimeographed, Maxwell Center for Demography and Economics of Aging.

Dunn T.A., Phillips J.W., (1997), "The timing and division of parental transfers to children”, Economics Letters, vol. 54, pp. 135-138.

Gouriéroux C., Monfort A., Renault E., Trognon A., (1987), "Simulated residuals", Journal of Econometrics, vol. 34, pp. 201-252.

Hayashi F., (1995), "Is the Japanese extended family altruistically linked ? Tests based on Engel curves", Journal of Political Economy, vol. 103, pp. 661-674.

Hochguertel S., Ohlsson H., (2003), “Compensatory inter vivos gifts”, Mimeographed, Goteborg University.

Jowett, J. (1991), "China: The one, two, three, four and more child policy”, Focus, vol. 41, pp. 3236.

Laferrère A., Wolff F.C., (2006), 'Microeconomic models of family transfers', in S.C. Kolm, J. Mercier Ythier (eds), Handbook on the Economics of Giving, Reciprocity and Altruism, NorthHolland, Elsevier, vol. 2, pp. 889-969. 
Laitner J., (1997), "Intergenerational and interhousehold economic links", in Rosenzweig M.R., Stark O., eds., Handbook of Population and Family Economics, vol. 1A, North-Holland, Amsterdam, pp. 189-238.

Light A., McGarry K., (2004), "Why parents play favorites: Explanations for unequal bequests", American Economic Review, vol. 94, pp. 1669-1681.

Lillard, L.A. , Willis, R.J., (1997), "Motives for intergenerational transfers: Evidence from Malaysia,” Demography, vol 34 (1), pp. 115-134.

Lindh T., Ohlsson H., (1998), "Self-employment and wealth inequality", Review of Income and Wealth, vol. 44, pp. 25-42.

Lucas R.E.B., Stark O., (1985), "Motivations to Remit: Evidence from Botswana”, Journal of Political Economy, vol. 93, pp. 901-18.

McGarry K., Schoeni R.F., (1995), "Transfer behavior in the Health and Retirement Study. Measurement and the redistribution of ressources within the family", Journal of Human Resources, vol. 30, pp. S185-S226.

McGarry K., Schoeni R.F., (1997), "Transfer behavior within the family: Results from the Asset and Health Dynamics survey", Journal of Gerontology: Social Sciences, vol. 52B, pp. 82-92.

Mayer C., Engelhardt G., (1996), "Gifts, down payments, and housing affordability", Journal of Housing Research, vol. 7, pp. 59-78.

Radford M., (2000), "The inheritance rights of women under Jewish and Islamic law", International and Comparative Law Journal, Spring.

Schoeni R.F., (2002), “Does unemployment insurance displace familial assistance ?”, Public Choice, vol. 110, pp. 99-119.

Spilerman S., (2004), “The impact of parental wealth on early living standards in Israel”, American Journal of Sociology, vol. 110 (1), pp. 92-122.

Spilerman S., Elmelech T., (2003), "Israeli attitudes about inter vivos transfers", in Bengtson V.L., Lowenstein A., (eds.), Global Aging and Challenges to Families, Aldine, New York, pp. 175195.

Stark, O., 1995, Altruism and Beyond, Cambridge: Cambridge University Press.

Wilhelm M.O., (1996), "Bequest behavior and the effect of heir's earnings : Testing the altruistic model of bequests", American Economic Review, vol. 86, pp. 874-892.

Wolff F.C., (2000), “Transferts monétaires inter vivos et cycle de vie”, Revue Economique, vol. 51, pp. 1419-1452. 
Table 1. Descriptive statistics of the sample, by religion

\begin{tabular}{|c|c|c|c|c|c|c|c|}
\hline \multirow[b]{2}{*}{ Variables } & \multicolumn{3}{|c|}{ Non Muslim } & \multicolumn{3}{|c|}{ Muslim } & \multirow[b]{2}{*}{$\begin{array}{l}\text { (7) } \\
\text { All }\end{array}$} \\
\hline & $\begin{array}{c}(1) \\
\text { No gift }\end{array}$ & $\begin{array}{c}(2) \\
\text { Gift }^{1}\end{array}$ & $\begin{array}{l}\text { (3) } \\
\text { All }\end{array}$ & $\begin{array}{c}(4) \\
\text { No gift }\end{array}$ & $\begin{array}{c}(5) \\
\text { Gift }\end{array}$ & (6) & \\
\hline Financial transfers: & & & & & & & \\
\hline Receipt of transfer & 0.000 & 1.000 & 0.129 & 0.000 & 1.000 & 0.043 & 0.092 \\
\hline \multicolumn{8}{|l|}{ Characteristics of the parent: } \\
\hline Age & 58.547 & 58.337 & 58.519 & 57.492 & 57.858 & 57.508 & 58.085 \\
\hline Lives with partner & 0.827 & 0.858 & 0.831 & 0.841 & 0.810 & 0.840 & 0.835 \\
\hline Number of children at home & 0.955 & 0.453 & 0.890 & 2.493 & 1.735 & 2.460 & 1.564 \\
\hline Number of children outside home & 2.484 & 2.275 & 2.457 & 3.425 & 3.470 & 3.427 & 2.874 \\
\hline Years of education & 7.881 & 10.095 & 8.168 & 3.432 & 4.419 & 3.474 & 6.152 \\
\hline Health problems & 0.307 & 0.278 & 0.303 & 0.379 & 0.360 & 0.378 & 0.336 \\
\hline Currently working & 0.394 & 0.449 & 0.401 & 0.277 & 0.324 & 0.279 & 0.348 \\
\hline Household's income (log) & 9.701 & 10.032 & 9.744 & 9.446 & 9.510 & 9.449 & 9.617 \\
\hline Home owner & 0.604 & 0.726 & 0.620 & 0.279 & 0.281 & 0.279 & 0.474 \\
\hline Duration since migration $(/ 100)$ & 0.349 & 0.359 & 0.350 & 0.323 & 0.323 & 0.323 & 0.339 \\
\hline French citizenship & 0.406 & 0.497 & 0.418 & 0.169 & 0.198 & 0.170 & 0.312 \\
\hline Difficulties in reading French & \multicolumn{7}{|c|}{ Origin country: } \\
\hline Northern Europe & 0.078 & 0.190 & 0.092 & 0.000 & 0.000 & 0.000 & 0.053 \\
\hline Southern Europe & 0.611 & 0.528 & 0.600 & 0.002 & 0.000 & 0.002 & 0.343 \\
\hline Eastern Europe & 0.050 & 0.062 & 0.052 & 0.005 & 0.020 & 0.005 & 0.032 \\
\hline Northern Africa & 0.089 & 0.102 & 0.091 & 0.878 & 0.810 & 0.875 & 0.428 \\
\hline Central and Southern Africa & 0.059 & 0.026 & 0.055 & 0.031 & 0.036 & 0.031 & 0.045 \\
\hline America & 0.018 & 0.031 & 0.019 & 0.000 & 0.000 & 0.000 & 0.011 \\
\hline Middle East & 0.019 & 0.014 & 0.018 & 0.081 & 0.130 & 0.083 & 0.046 \\
\hline Asia & 0.076 & 0.047 & 0.073 & 0.004 & 0.004 & 0.004 & 0.043 \\
\hline Religion: & & & & & & & \\
\hline Catholic & 0.702 & 0.695 & 0.701 & 0.000 & 0.000 & 0.000 & 0.400 \\
\hline Muslim & 0.000 & 0.000 & 0.000 & 1.000 & 1.000 & 1.000 & 0.429 \\
\hline Protestant & 0.045 & 0.078 & 0.049 & 0.000 & 0.000 & 0.000 & 0.028 \\
\hline Other Christian & 0.055 & 0.057 & 0.056 & 0.000 & 0.000 & 0.000 & 0.032 \\
\hline Other religion & 0.109 & 0.099 & 0.108 & 0.000 & 0.000 & 0.000 & 0.062 \\
\hline No religion & 0.089 & 0.071 & 0.086 & 0.000 & 0.000 & 0.000 & 0.049 \\
\hline Characteristics of the child: & & & & & & & \\
\hline Female & 0.488 & 0.491 & 0.488 & 0.500 & 0.391 & 0.495 & 0.491 \\
\hline Age & 30.928 & 30.956 & 30.932 & 28.661 & 30.111 & 28.723 & 29.983 \\
\hline Lives with partner & 0.567 & 0.617 & 0.574 & 0.444 & 0.478 & 0.445 & 0.519 \\
\hline Number of children & 0.866 & 0.809 & 0.858 & 0.806 & 1.166 & 0.821 & 0.842 \\
\hline Years of education & 11.756 & 13.197 & 11.943 & 9.569 & 7.763 & 9.492 & 10.890 \\
\hline Occupation: Working & 0.731 & 0.735 & 0.731 & 0.541 & 0.395 & 0.535 & 0.647 \\
\hline Student & 0.102 & 0.121 & 0.105 & 0.135 & 0.119 & 0.134 & 0.117 \\
\hline Unemployed & 0.070 & 0.058 & 0.069 & 0.140 & 0.170 & 0.141 & 0.100 \\
\hline Inactive & 0.097 & 0.086 & 0.095 & 0.184 & 0.316 & 0.190 & 0.136 \\
\hline Financial status: Rich & 0.348 & 0.334 & 0.346 & 0.208 & 0.111 & 0.204 & 0.285 \\
\hline Fair & 0.524 & 0.476 & 0.518 & 0.579 & 0.447 & 0.574 & 0.542 \\
\hline Poor & 0.127 & 0.190 & 0.136 & 0.212 & 0.443 & 0.222 & 0.173 \\
\hline In France, at home & 0.255 & 0.115 & 0.237 & 0.364 & 0.162 & 0.355 & 0.287 \\
\hline In France, less than $10 \mathrm{kms}$ & 0.303 & 0.283 & 0.301 & 0.272 & 0.206 & 0.269 & 0.287 \\
\hline In France, more than $10 \mathrm{kms}$ & 0.350 & 0.427 & 0.360 & 0.240 & 0.162 & 0.237 & 0.307 \\
\hline Does not live in France & 0.092 & 0.174 & 0.103 & 0.124 & 0.470 & 0.139 & 0.118 \\
\hline Number of observations & 6836 & 1016 & 7852 & 5657 & 253 & 5910 & 13762 \\
\hline
\end{tabular}

Source: Survey PRI 2003.

1. Receipt of transfer within past 5 years. 
Table 2. Receipt of financial transfers, by parent's origin country and religion ${ }^{1}$

\begin{tabular}{|c|c|c|c|c|c|}
\hline \multirow{2}{*}{ Variables } & \multirow{2}{*}{$\begin{array}{l}\text { Number of } \\
\text { children }\end{array}$} & \multirow{2}{*}{$\begin{array}{l}\text { Number of } \\
\text { families }\end{array}$} & \multirow{2}{*}{$\begin{array}{c}\% \text { of receipt by } \\
\text { a child }\end{array}$} & \multicolumn{2}{|c|}{ Mean value per recipient (euros) } \\
\hline & & & & $\begin{array}{l}\text { Category } \\
\text { midpoint }\end{array}$ & Simulated \\
\hline \multicolumn{6}{|l|}{ Origin country: } \\
\hline Europe & 5881 & 2559 & 13.6 & 3208 & 3107 \\
\hline Northern Europe & 723 & 318 & 26.7 & 3047 & 2853 \\
\hline Southern Europe & 4720 & 2025 & 11.4 & 3389 & 3310 \\
\hline Eastern Europe & 438 & 216 & 15.5 & 2238 & 2228 \\
\hline Africa & 6500 & 1939 & 5.3 & 1889 & 1749 \\
\hline Northern Africa & 5884 & 1681 & 5.3 & 1944 & 1806 \\
\hline Central and Southern Africa & 616 & 258 & 5.7 & 1397 & 1243 \\
\hline America & 152 & 69 & 21.1 & 2028 & 1949 \\
\hline Middle-East & 638 & 197 & 7.4 & 1709 & 1714 \\
\hline Asia & 591 & 235 & 8.3 & 2227 & 1941 \\
\hline \multicolumn{6}{|l|}{ Religion: } \\
\hline Non-Muslim & 7852 & 3359 & 12.9 & 3120 & 3002 \\
\hline Catholic & 5505 & 2364 & 12.8 & 3210 & 3101 \\
\hline Protestant & 386 & 160 & 20.5 & 2965 & 2779 \\
\hline Other Christian & 437 & 212 & 13.3 & 2227 & 2171 \\
\hline Other & 847 & 351 & 11.9 & 2810 & 2787 \\
\hline No religion & 677 & 272 & 10.6 & 3570 & 3240 \\
\hline Muslim & 5910 & 1640 & 4.3 & 1147 & 1053 \\
\hline Total & 13762 & 4999 & 9.2 & 2727 & 2613 \\
\hline
\end{tabular}

Source: Survey PRI 2003.

1. Receipt of transfer within past five years. 
Table 3. Parental reasons for making financial transfers

\begin{tabular}{|c|c|c|c|c|c|c|}
\hline \multirow[t]{2}{*}{ Reason for making transfer } & \multicolumn{2}{|c|}{$\begin{array}{c}(1) \\
\text { All }(\mathrm{N}=1269) \\
\end{array}$} & \multicolumn{2}{|c|}{$\begin{array}{c}(2) \\
\text { Muslim (N=253) }\end{array}$} & \multicolumn{2}{|c|}{$\begin{array}{c}(3) \\
\text { Non-muslim }(\mathrm{N}=1016)\end{array}$} \\
\hline & $\%$ giving & Amount & $\%$ giving & Amount & $\%$ giving & Amount \\
\hline Help because of financial need & 42.9 & 1555 & 73.1 & 905 & 35.4 & 1890 \\
\hline Help to buy a dwelling & 13.8 & 7575 & 6.3 & 2865 & 15.6 & 8050 \\
\hline Help for other non-housing expenditures & 6.9 & 2145 & 2.4 & 1540 & 8.0 & 2190 \\
\hline "Happy" family event & 8.6 & 1135 & 3.6 & 770 & 9.8 & 1170 \\
\hline Help for schooling expenditures & 6.9 & 3080 & 4.0 & 2420 & 7.6 & 3165 \\
\hline To make a gift & 15.9 & 1180 & 7.5 & 1205 & 18.0 & 1175 \\
\hline Other & 5.0 & 7510 & 3.2 & 1980 & 5.5 & 8300 \\
\hline Total & 100.0 & 2735 & 100.0 & 1155 & 100.0 & 3130 \\
\hline
\end{tabular}

Source: Survey PRI 2003.

The sample is restricted to positive transfers. 
Table 4. Occurrence of unequal and equal sharing

\begin{tabular}{|c|c|c|c|c|c|}
\hline \multicolumn{6}{|c|}{ A. All } \\
\hline $\begin{array}{l}\text { Number of childen } \\
\text { per family }\end{array}$ & $\begin{array}{c}\text { (1) } \\
\text { Number of } \\
\text { families }\end{array}$ & $\begin{array}{c}(2) \\
\text { No recipient }\end{array}$ & $\begin{array}{c}\text { (3) } \\
\text { One child at } \\
\text { least, but not all }\end{array}$ & $\begin{array}{c}(4) \\
\text { All children } \\
\text { receive }\end{array}$ & $\begin{array}{c}\text { (5) } \\
(3) /(4)\end{array}$ \\
\hline 1 & 1164 & 87.2 & - & 12.8 & - \\
\hline 2 & 1601 & 81.4 & 7.7 & 10.8 & 0.71 \\
\hline 3 & 989 & 82.1 & 11.9 & 6.0 & 1.98 \\
\hline 4 & 559 & 85.2 & 12.0 & 2.9 & 4.14 \\
\hline More than 2 & 3149 & 82.3 & 9.8 & 7.9 & 1.24 \\
\hline
\end{tabular}

B. Muslim

\begin{tabular}{|l|c|c|c|c|c|}
\hline $\begin{array}{l}\text { Number of childen } \\
\text { per family }\end{array}$ & $\begin{array}{c}\text { Number of } \\
\text { families }\end{array}$ & No recipient & $\begin{array}{c}\text { 0ne recipient at } \\
\text { least, but not all }\end{array}$ & All recipient & $(3) /(4)$ \\
\hline 1 & 253 & 93.7 & - & 6.3 & - \\
2 & 329 & 91.8 & 5.5 & 2.7 & 2.04 \\
3 & 304 & 88.5 & 10.5 & 1.0 & 10.50 \\
4 & 274 & 89.4 & 9.9 & 0.7 & 14.14 \\
\hline More than 2 & 907 & 90.0 & 8.5 & 1.5 & 5.67 \\
\hline
\end{tabular}

C. Non Muslim

\begin{tabular}{|l|c|c|c|c|c|}
\hline $\begin{array}{l}\text { Number of childen } \\
\text { per family }\end{array}$ & $\begin{array}{c}\text { Number of } \\
\text { families }\end{array}$ & No recipient & $\begin{array}{c}\text { One recipient at } \\
\text { least, but not all }\end{array}$ & All recipient & $(3) /(4)$ \\
\hline 1 & 911 & 85.4 & - & 14.6 & - \\
2 & 1272 & 78.8 & 8.3 & 12.9 & 0.64 \\
3 & 685 & 79.3 & 12.6 & 8.2 & 1.54 \\
4 & 285 & 81.1 & 14.0 & 4.9 & 2.86 \\
\hline More than 2 & 2242 & 79.2 & 10.3 & 10.4 & 0.99 \\
\hline
\end{tabular}

Source: Survey PRI 2003.

Families with more than 4 children are excluded from the sample. 
Table 5. Estimates for transfers received by children

\begin{tabular}{|c|c|c|c|c|c|c|c|}
\hline \multirow{2}{*}{\multicolumn{2}{|c|}{ Variables }} & \multirow{2}{*}{$\begin{array}{l}\text { (1) } \\
\text { Random } \\
\text { effects Probit }\end{array}$} & \multirow{2}{*}{$\begin{array}{l}\text { (2) } \\
\text { Conditional } \\
\text { (Fixed effects) } \\
\text { Logit }\end{array}$} & \multicolumn{2}{|c|}{ Random effects Tobit } & \multirow{2}{*}{$\begin{array}{l}(5) \\
\text { Interval } \\
\text { regression }\end{array}$} & \multirow{2}{*}{$\begin{array}{l}\text { (6) } \\
\text { Probit for } \\
\text { unequal sharing }\end{array}$} \\
\hline & & & & $\begin{array}{c}\text { (3) } \\
\text { Midpoint }\end{array}$ & $\begin{array}{l}(4) \\
\text { Simulated }\end{array}$ & & \\
\hline \multicolumn{2}{|l|}{ Constant } & $\begin{array}{c}-20.862^{* * *} \\
(5.58)\end{array}$ & & $\begin{array}{c}-97.835^{* * *} \\
(5.58)\end{array}$ & $\begin{array}{l}-94.657^{* * *} \\
(5.79)\end{array}$ & $\begin{array}{l}-7.505^{* * *} \\
(5.11)\end{array}$ & $\begin{array}{l}-4.916 \\
(1.05)\end{array}$ \\
\hline \multicolumn{8}{|c|}{ Characteristics of the parent: } \\
\hline \multicolumn{2}{|c|}{ Age } & $\begin{array}{l}0.479^{* * *} \\
(3.71)\end{array}$ & & $\begin{array}{l}2.176^{* * *} \\
(3.57)\end{array}$ & $\begin{array}{l}2.109^{* * *} \\
(3.71)\end{array}$ & $\begin{array}{l}0.194^{* * *} \\
(3.78)\end{array}$ & $\begin{array}{c}0.169 \\
(1.06)\end{array}$ \\
\hline \multicolumn{2}{|c|}{ Age squared $\left(10^{\mathrm{c}}-2\right)$} & $\begin{array}{l}-0.415^{* * *} \\
(3.70)\end{array}$ & & $\begin{array}{l}-1.900^{* * *} \\
(3.59)\end{array}$ & $\begin{array}{l}-1.831^{* * *} \\
(3.72)\end{array}$ & $\begin{array}{l}-0.164^{* * *} \\
(3.67)\end{array}$ & $\begin{array}{l}-0.140 \\
(1.03)\end{array}$ \\
\hline \multicolumn{2}{|l|}{ Lives with partner } & $\begin{array}{l}-0.005 \\
(0.04)\end{array}$ & & $\begin{array}{l}-0.200 \\
(0.30)\end{array}$ & $\begin{array}{l}-0.232 \\
(0.37)\end{array}$ & $\begin{array}{c}0.045 \\
(0.80)\end{array}$ & $\begin{array}{l}-0.254 \\
(1.42)\end{array}$ \\
\hline \multicolumn{2}{|c|}{ Number of children at home } & $\begin{array}{l}-0.311^{* * *} \\
(6.29)\end{array}$ & & $\begin{array}{l}-1.486^{* * *} \\
(6.38)\end{array}$ & $\begin{array}{l}-1.332^{* * *} \\
(5.70)\end{array}$ & $\begin{array}{l}-0.087^{* * *} \\
(7.53)\end{array}$ & $\begin{array}{l}0.624^{* * *} \\
(6.45)\end{array}$ \\
\hline \multicolumn{2}{|c|}{ Number of children outside home } & $\begin{array}{l}-0.159^{* * *} \\
(5.36)\end{array}$ & & $\begin{array}{l}-0.750^{* * *} \\
(5.49)\end{array}$ & $\begin{array}{l}-0.756^{* * *} \\
(5.76)\end{array}$ & $\begin{array}{l}-0.084^{* * *} \\
(7.44)\end{array}$ & $\begin{array}{l}0.401^{* * *} \\
(5.01)\end{array}$ \\
\hline \multicolumn{2}{|l|}{ Years of education } & $\begin{array}{l}0.049^{* * *} \\
(4.11)\end{array}$ & & $\begin{array}{l}0.211^{* * *} \\
(3.74)\end{array}$ & $\begin{array}{l}0.196^{* * *} \\
(3.75)\end{array}$ & $\begin{array}{l}0.029^{* * *} \\
(4.45)\end{array}$ & $\begin{array}{l}-0.031^{* *} \\
(2.25)\end{array}$ \\
\hline \multicolumn{2}{|l|}{ Health problems } & $\begin{array}{c}0.062 \\
(0.58)\end{array}$ & & $\begin{array}{c}0.288 \\
(0.56)\end{array}$ & $\begin{array}{c}0.270 \\
(0.56)\end{array}$ & $\begin{array}{l}-0.039 \\
(0.88)\end{array}$ & $\begin{array}{c}0.021 \\
(0.16)\end{array}$ \\
\hline \multicolumn{2}{|l|}{ Currently working } & $\begin{array}{c}0.017 \\
(0.14)\end{array}$ & & $\begin{array}{c}0.052 \\
(0.10)\end{array}$ & $\begin{array}{c}0.043 \\
(0.08)\end{array}$ & $\begin{array}{l}-0.022 \\
(0.39)\end{array}$ & $\begin{array}{l}-0.088 \\
(0.63)\end{array}$ \\
\hline \multicolumn{2}{|c|}{ Household's income (log) } & $\begin{array}{l}0.288^{* * *} \\
(4.57)\end{array}$ & & $\begin{array}{l}1.556^{* * *} \\
(5.21)\end{array}$ & $\begin{array}{l}1.526^{* * *} \\
(5.28)\end{array}$ & $\begin{array}{l}0.176^{* * *} \\
(6.62)\end{array}$ & $\begin{array}{l}-0.048 \\
(0.56)\end{array}$ \\
\hline \multicolumn{2}{|l|}{ Home owner } & $\begin{array}{l}0.251^{* *} \\
(2.22)\end{array}$ & & $\begin{array}{l}1.328^{* *} \\
(2.41)\end{array}$ & $\begin{array}{l}1.270^{* *} \\
(2.46)\end{array}$ & $\begin{array}{l}0.132^{* * *} \\
(2.95)\end{array}$ & $\begin{array}{c}0.107 \\
(0.72)\end{array}$ \\
\hline \multicolumn{2}{|c|}{ Duration since migration } & $\begin{array}{l}1.135^{* *} \\
(2.20)\end{array}$ & & $\begin{array}{l}5.762^{* * *} \\
(2.70)\end{array}$ & $\begin{array}{l}5.111^{* *} \\
(2.47)\end{array}$ & $\begin{array}{c}0.314 \\
(1.12)\end{array}$ & $\begin{array}{l}-0.718 \\
(1.26)\end{array}$ \\
\hline \multicolumn{2}{|l|}{ French citizenship } & $\begin{array}{l}0.025 \\
(0.22)\end{array}$ & & $\begin{array}{c}0.391 \\
(0.77)\end{array}$ & $\begin{array}{c}0.471 \\
(0.96)\end{array}$ & $\begin{array}{c}0.060 \\
(1.11)\end{array}$ & $\begin{array}{l}-0.042 \\
(0.33)\end{array}$ \\
\hline \multicolumn{2}{|c|}{ Difficulties in reading French } & $\begin{array}{l}-0.410^{* * *} \\
(3.24)\end{array}$ & & $\begin{array}{l}-2.089^{* * *} \\
(3.51)\end{array}$ & $\begin{array}{l}-1.930^{* * *} \\
(3.49)\end{array}$ & $\begin{array}{l}-0.122^{* * *} \\
(2.66)\end{array}$ & $\begin{array}{l}-0.055 \\
(0.35)\end{array}$ \\
\hline \multicolumn{2}{|l|}{ Muslim } & $\begin{array}{l}-0.248^{*} \\
(1.70)\end{array}$ & & $\begin{array}{l}-1.336^{* *} \\
(1.98)\end{array}$ & $\begin{array}{l}-1.437^{* *} \\
(2.19)\end{array}$ & $\begin{array}{l}-0.082^{*} \\
(1.82)\end{array}$ & $\begin{array}{l}0.516^{* *} \\
(2.48)\end{array}$ \\
\hline \multicolumn{8}{|c|}{ Characteristics of the child: } \\
\hline \multicolumn{2}{|c|}{ Female } & $\begin{array}{l}-0.249^{* * *} \\
(3.92)\end{array}$ & $\begin{array}{l}-0.617^{* * *} \\
(4.35)\end{array}$ & $\begin{array}{l}-1.098^{* * *} \\
(3.82)\end{array}$ & $\begin{array}{l}-1.042^{* * *} \\
(3.80)\end{array}$ & $\begin{array}{l}-0.046 \\
(1.37)\end{array}$ & \\
\hline \multicolumn{2}{|l|}{ Age } & $\begin{array}{c}0.033 \\
(0.74)\end{array}$ & $\begin{array}{l}-0.037 \\
(0.39)\end{array}$ & $\begin{array}{c}0.147 \\
(0.71)\end{array}$ & $\begin{array}{c}0.129 \\
(0.66)\end{array}$ & $\begin{array}{c}0.010 \\
(0.52)\end{array}$ & \\
\hline \multicolumn{2}{|c|}{ Age squared $\left(10^{\mathrm{c}}-2\right)$} & $\begin{array}{l}-0.044 \\
(0.67)\end{array}$ & $\begin{array}{l}0.076 \\
(0.53)\end{array}$ & $\begin{array}{l}-0.211 \\
(0.67)\end{array}$ & $\begin{array}{l}-0.193 \\
(0.64)\end{array}$ & $\begin{array}{l}-0.014 \\
(0.49)\end{array}$ & \\
\hline \multicolumn{2}{|l|}{ Lives with partner } & $\begin{array}{l}-0.102 \\
(1.23)\end{array}$ & $\begin{array}{l}-0.129 \\
(0.70)\end{array}$ & $\begin{array}{l}-0.490 \\
(1.32)\end{array}$ & $\begin{array}{l}-0.415 \\
(1.17)\end{array}$ & $\begin{array}{c}0.009 \\
(0.19)\end{array}$ & \\
\hline Number of childr & & $\begin{array}{l}0.016 \\
(0.49)\end{array}$ & $\begin{array}{l}0.022 \\
(0.35)\end{array}$ & $\begin{array}{c}0.016 \\
(0.10)\end{array}$ & $\begin{array}{c}0.011 \\
(0.08)\end{array}$ & $\begin{array}{l}-0.011 \\
(0.65)\end{array}$ & \\
\hline Years of education & & $\begin{array}{l}0.006 \\
(0.75)\end{array}$ & $\begin{array}{c}0.009 \\
(0.55)\end{array}$ & $\begin{array}{c}0.035 \\
(0.96)\end{array}$ & $\begin{array}{c}0.035 \\
(1.01)\end{array}$ & $\begin{array}{l}0.007^{* *} \\
(2.05)\end{array}$ & \\
\hline $\begin{array}{l}\text { Occupation: } \\
\text { (ref: Working) }\end{array}$ & Student & $\begin{array}{l}0.575^{* * *} \\
(4.57)\end{array}$ & $\begin{array}{l}1.015^{* * *} \\
(3.67)\end{array}$ & $\begin{array}{l}2.614^{* * *} \\
(4.63)\end{array}$ & $\begin{array}{l}2.547^{* * *} \\
(4.75)\end{array}$ & $\begin{array}{l}0.306^{* * *} \\
(4.56)\end{array}$ & \\
\hline & Unemployed & $\begin{array}{l}0.211^{*} \\
(1.79)\end{array}$ & $\begin{array}{c}0.329 \\
(1.31)\end{array}$ & $\begin{array}{l}1.052^{*} \\
(1.92)\end{array}$ & $\begin{array}{l}1.025^{*} \\
(1.95)\end{array}$ & $\begin{array}{l}0.048 \\
(0.93)\end{array}$ & \\
\hline & Inactive & $\begin{array}{l}0.238^{* *} \\
(2.39)\end{array}$ & $\begin{array}{l}0.488^{* *} \\
(2.42)\end{array}$ & $\begin{array}{l}1.236^{* * *} \\
(2.63)\end{array}$ & $\begin{array}{l}1.137^{* *} \\
(2.52)\end{array}$ & $\begin{array}{l}0.020 \\
(0.36)\end{array}$ & \\
\hline $\begin{array}{l}\text { Financial status: } \\
\text { (ref: Rich) }\end{array}$ & Fair & $\begin{array}{l}0.228^{* * *} \\
(2.75)\end{array}$ & $\begin{array}{l}0.543^{* * *} \\
(2.75)\end{array}$ & $\begin{array}{l}1.063^{* * *} \\
(2.82)\end{array}$ & $\begin{array}{l}1.030^{* * *} \\
(2.87)\end{array}$ & $\begin{array}{l}0.099^{* *} \\
(2.24)\end{array}$ & \\
\hline & Poor & $\begin{array}{l}1.018^{* * *} \\
(9.46)\end{array}$ & $\begin{array}{l}1.640^{* * *} \\
(6.92)\end{array}$ & $\begin{array}{l}4.797^{* * *} \\
(9.84)\end{array}$ & $\begin{array}{l}4.655^{* * *} \\
(9.99)\end{array}$ & $\begin{array}{l}0.506^{* * *} \\
(7.75)\end{array}$ & \\
\hline $\begin{array}{l}\text { Distance: In Fr } \\
\text { (ref: In France, at }\end{array}$ & $\begin{array}{l}\text { ance, less than } 10 \mathrm{kms} \\
\text { home) }\end{array}$ & $\begin{array}{l}0.727^{* * *} \\
(5.97)\end{array}$ & $\begin{array}{l}0.928^{* * *} \\
(3.56)\end{array}$ & $\begin{array}{l}3.457^{* * *} \\
(6.11)\end{array}$ & $\begin{array}{l}3.310^{* * *} \\
(6.15)\end{array}$ & $\begin{array}{l}0.401^{* * *} \\
(7.03)\end{array}$ & \\
\hline In $\mathrm{F}$ & rance, more than $10 \mathrm{kms}$ & $\begin{array}{l}0.875^{* * *} \\
(7.40)\end{array}$ & $\begin{array}{l}1.055^{* * *} \\
(4.24)\end{array}$ & $\begin{array}{l}4.077^{* * *} \\
(7.48)\end{array}$ & $\begin{array}{l}3.924^{* * *} \\
(7.56)\end{array}$ & $\begin{array}{l}0.498^{* * *} \\
(8.70)\end{array}$ & \\
\hline Doe & es not live in France & $\begin{array}{l}1.620^{* * *} \\
(11.49)\end{array}$ & $\begin{array}{l}1.960^{* * *} \\
(6.51)\end{array}$ & $\begin{array}{l}7.456^{* * *} \\
(11.45)\end{array}$ & $\begin{array}{l}7.158^{* * *} \\
(11.48)\end{array}$ & $\begin{array}{l}0.972^{* * *} \\
(11.12)\end{array}$ & \\
\hline Number of observat & tions & 13762 & 1449 & 13762 & 13762 & 13762 & 557 \\
\hline Number of families & & 4999 & 401 & 4999 & 4999 & 4999 & 557 \\
\hline Log likelihood & & -3019.3 & -441.5 & -6557.6 & -6487.8 & -27670.0 & -325.6 \\
\hline
\end{tabular}

Absolute values of t-statistics are in parentheses. Significant levels are respectively $1 \%\left(^{(* *}\right), 5 \%\left({ }^{* *}\right)$, and $10 \%\left(^{*}\right)$.

Table 6. Estimates for transfers received by children, by religion 


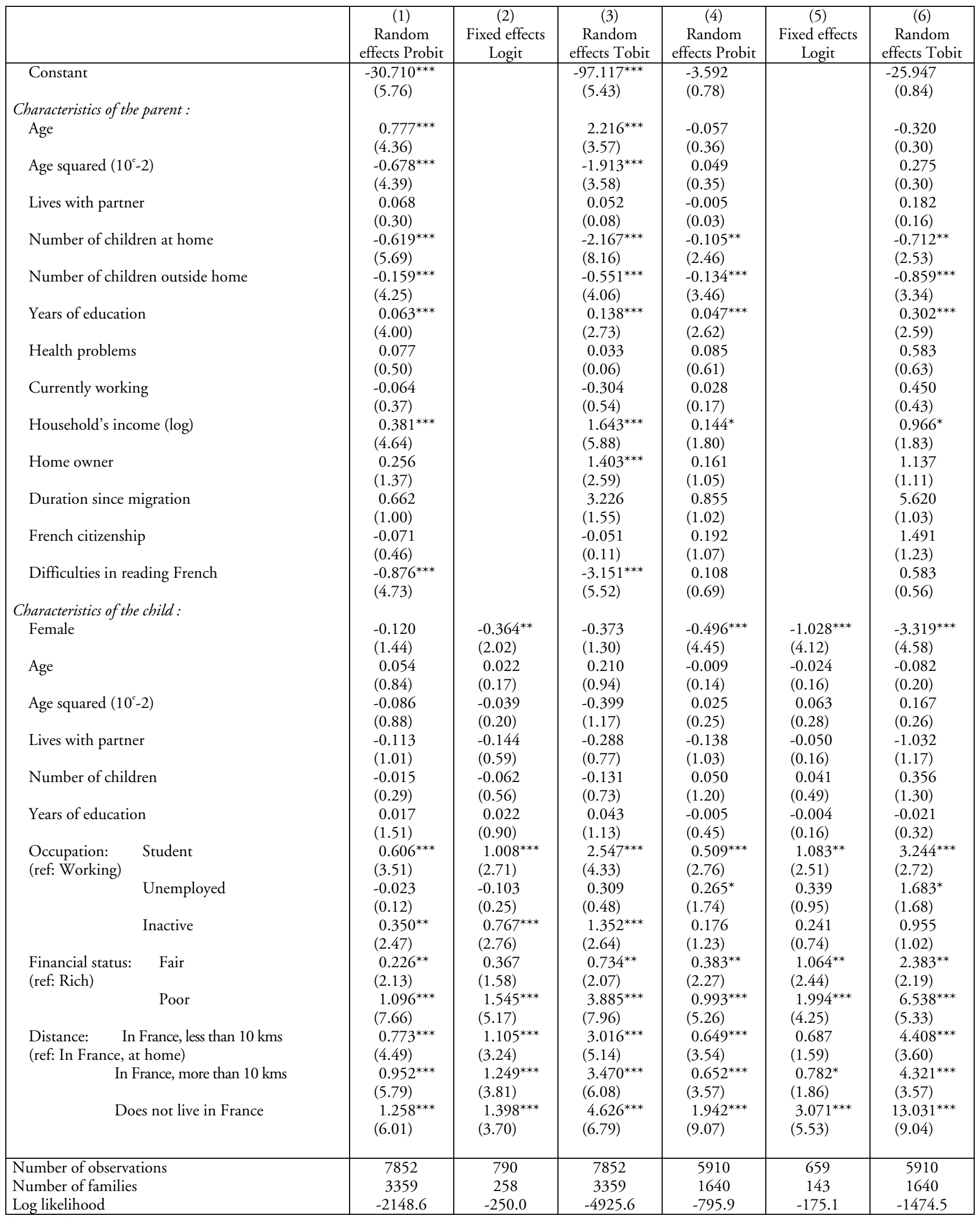

Source: Survey PRI 2003.

Absolute values of $\mathrm{t}$-statistics are in parentheses. Significance levels are respectively $1 \%\left({ }^{(*)}\right), 5 \%\left(\left(^{\circ}\right)\right.$, and $10 \%\left(\left(^{\circ}\right.\right.$ ). 
Figure 1 . The impact of parental income on the probability of a gift receipt, by religion

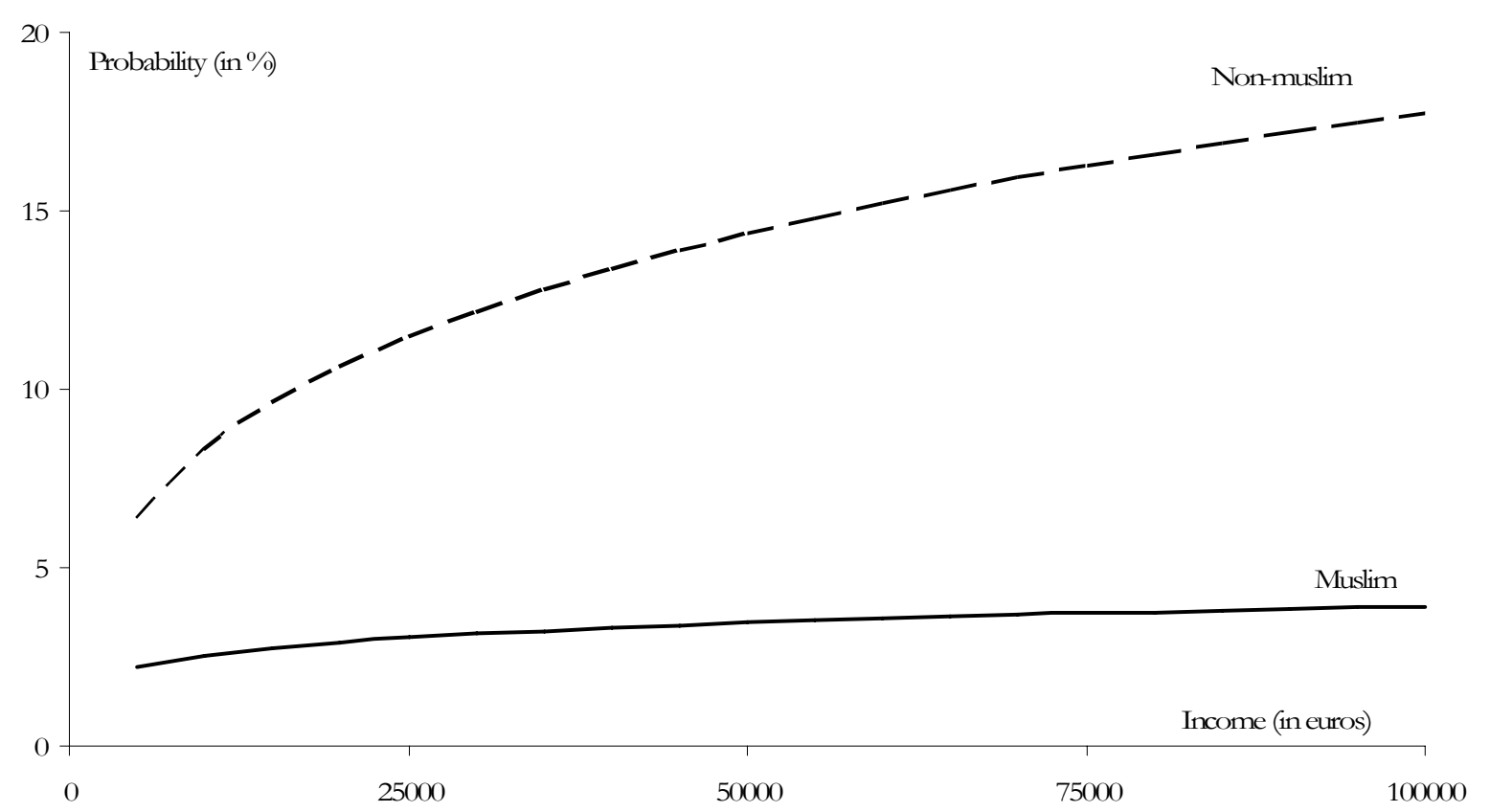

Source: Survey PRI 2003. 


\section{ISERP Working Papers}

$\underline{2007}$

07-12: "Household Wealth in Latin America," Florencia Torche, Sociology, NYU, Seymour Spilerman, Sociology, Columbia University

07-11: "Theoretical Formulations and Research Strategies in Sociology," Seymour Spilerman, Sociology, Columbia University, Emanuele Gerratana, Economics, KOC University

07-10: "Fiscal Spillovers between Local Governments: Keeping up with the Joneses' School District," Randall Reback, Barnard Economics, Columbia University

07-09: "Long-Term Effects of a Recession at Labor Market Entry in Japan and the United States," Yuji Genda, Institute of Social Science, University of Tokyo, Ayako Kondo, ISERP Graduate Fellow, Economics, Columbia University, Souichi Ohta, Economics, Keio University

07-08: "Simultaneous Estimation of Hedonic Equations with Unbalanced Data," Valerie A. Mueller, Earth Institute, Columbia University, Glenn Sheriff, School of International and Public Affairs, Columbia University

07-07: "Poverty Analysis Based on Kernel Density Estimates from Grouped Data," Camelia Minoiu, Economics, Columbia University

07-06: “Does Gaming the System Affect Students' Academic Achievement?" Jennifer BooherJennings, Sociology, Columbia University, Andrew A. Beveridge, Sociology, Queens College and CUNY Graduate Center

07-05: "Differential Effects of Graduating During a Recession across Race and Gender," Ayako Kondo, Economics, Graduate Fellow, ISERP, Columbia University

07-04: "PowerPoint Demonstrations: Digital Technologies of Persuasion," David Stark, Sociology, Columbia University, Verena Paravel, Center on Organizational Innovation, ISERP, Columbia University

07-03: "No Entiendo: The Effects of Bilingualism on Hispanic Earnings," Jeronimo Cortina, Political Science, Columbia University, Rodolfo de la Garza, Political Science and International Affairs and Public Affairs, Columbia University, Pablo Pinto, Political Science, Columbia University

07-02: "The Assessment of Poverty and Inequality through Parametric Estimation of Lorenz Curves," Camelia Minoiu, Economics, Columbia University, Sanjay Reddy, Barnard Economics

07-01: "Implementing Second-Best Environmental Policy under Adverse Selection," Glenn Sheriff, School of International and Public Affairs, Columbia University

$\underline{2006}$

06-01: "The Impact of Parental Marital Disruption on Children's Performance in School," Christopher Weiss, ISERP, Columbia University, Kathleen Foley, University of Pennsylvania

06-02: “The Choice of Index Number: Part I, Valuation and Evaluation," Sanjay Reddy, Barnard Economics, Benjamin Plener, Yale University 
06-03: "Real Income Stagnation of Countries, 1960-2001," Sanjay Reddy, Barnard Economics, Camelia Minoiu, Economics, Columbia University

06-04: "Chinese Poverty: Assessing the Impact of Alternative Assumptions," Sanjay Reddy, Barnard Economics, Camelia Minoiu, Economics, Columbia University

06-05: "Spaghetti Politics," Paolo Parigi, Sociology, Columbia University, Peter Bearman, Sociology, Columbia University

06-06: "Attention Felons: Evaluating Project Safe Neighborhoods in Chicago," Andrew Papachristos, University of Chicago, Tracey Meares, University of Chicago, Jeffrey Fagan, Law, Columbia University

06-07: "Dynamics of Political Polarization," Delia Baladassarri, Columbia University, Peter Bearman, Columbia University

06-08: "Why do Some Countries Produce So Much More Output per Worker than Others?" Emmanuel Pikoulakis, University of Hull Business School, Camelia Minoiu, Economics, Columbia University

06-09: "Trivers-Willard at Birth and One Year: Evidence from U.S. Natality Data 1983-2001," Douglas Almond, Economics, Columbia University, Lena Edlund, Economics, Columbia University

06-10: "Forecasting House Seats from General Congressional Polls," Robert Erikson, Political Science, Columbia University

06-11: "From Drafts to Checks: The Evolution of Correspondent Banking Networks and the Formation of the Modern U.S. Payments System, 1850-1914," John James, Economics, University of Virginia, David Weiman, Economics, Barnard College, and History, Columbia University

\section{$\underline{2005}$}

05-01: "Social Construction of Flows: Price Profiles Across Producers Gear to Market Context Upstream, Downstream and Cross-Stream," Harrison White, Sociology, Columbia University

05-02: "Temporality and Intervention Effects: Trajectory Analysis of a Homeless Mental Health Program," Mary Clare Lennon, Public Health, Columbia University, William McAllister, ISERP, Li Kuang, Public Health, Columbia University, Daniel Herman, Public Health, Columbia University

05-03: "Do Parents Help More Their Less Well-off Children?: Evidence from a Sample of Migrants to France," François-Charles Wolff, Université de Nantés, Seymour Spilerman, Sociology, Columbia University, and Claudine Attias-Donfut, Caisse Nationale d'Assurance Vieillesse

05-04: "Politics, Public Bads, and Private Information," Glenn Sheriff, International and Public Affairs, Columbia University

05-05: "Determinants of Justification and Indulgence," Ran Kivetz, School of Business, Columbia University, Yuhuang Zheng, School of Business, Columbia University

05-06: "Political Competition and Policy Adoption: Market Reforms in Latin American Public Utilities," Victoria Murillo, International and Public Affairs, Columbia University, Cecilia Martinez-Gallardo, Centro de Investigación y Docéncia Económica 
05-07: "In Search of Lost Memories: Domestic Spheres and Identities in Roman Amheida, Egypt," Anna Lucille Boozer, Anthropology, ISERP Graduate Fellow, Columbia University

05-08: "Global Links, Local Roots: Varieties of Transnationalization and Forms of Civic Integration," David Stark, Sociology, Columbia University, Balazs Vedres, Central European University, Laszlo Bruszt, European University Institute

05-09: "Socio-Technologies of Assembly: Sense-Making and Demonstration in Rebuilding Lower Manhattan,” Monique Girard, ISERP, Columbia University, David Stark, Sociology, Columbia University

$\underline{2004}$

04-01: "Reducing Bias in Treatment Effect Estimation in Observational Studies Suffering from Missing Data," Jennifer Hill, International and Public Affairs, Columbia University

04-02: "Production Markets Broker Upstream to Downstream, balancing their volume and quality sensitivities to firms through an oriented market profile of signals," Harrison C. White, Sociology, Columbia University

04-03: "Measuring Economic Disadvantage During Childhood: A Group-Based Modeling Approach," Robert L. Wagmiller, Jr., SUNY Buffalo, Mary Clare Lennon, Public Health, Columbia University, Philip M. Alberti, Public Health, Columbia University, and J. Lawrence Aber, New York University

04-04: "Policymaking and Caseload Dynamics: Homeless Shelters," William McAllister, ISERP, and Gordon Berlin, Columbia University

04-05: "Fresh Starts: School Form and Student Outcomes," Christopher Weiss, ISERP, Columbia University and Peter S. Bearman, Sociology, ISERP, Columbia University

04-06: "Parental Wealth Effects On Living Standards and Asset Holdings: Results From Chile," Florencia Torche, Sociology, Queens College, Center for the Study of Wealth and Inequality, Columbia University and Seymour Spilerman, Sociology, Center for the Study of Wealth and Inequality, Columbia University

04-07: "Routes into Networks: The Structure of English Trade in the East Indies, 1601-1833," Emily Erikson, Sociology, ISERP, Columbia University and Peter Bearman, Sociology, ISERP, Columbia University

$\underline{2003}$

03-01: "The Plasticity of Participation: Evidence From a Participatory Governance Experiment," Shubham Chaudhuri, Economics, Columbia University, and Patrick Heller, Sociology, Brown University

03-02: "Factional Politics and Credit Networks in Revolutionary Vermont," Henning Hillmann, Sociology, Columbia University

03-03: " 'Active Patients' in Rural African Health Care: Implications for Welfare, Policy and Privatization,” Kenneth L. Leonard, Economics, Columbia University 
03-04: "Living at the Edge: America's Low-Income Children and Families," Hsien-Hen Lu, Public Health, Columbia University, Julian Palmer, Younghwan Song, Economics, Union College, Mary Clare Lennon, Public Health, Columbia University, Lawrence Aber, Public Health, Columbia University

$\underline{2002}$

02-01: "Alternative Models of Dynamics in Binary Time-Series-Cross-Section Models: The Example of State Failure," Nathaniel Beck, Political Science, UC San Diego, David Epstein, Political Science, Columbia, Simon Jackman, Political Science, Stanford and Sharyn O'Halloran, Political Science, Columbia

02-03: "Link, Search, Interact: The Co-Evolution of NGOs and Interactive Technology," Jonathan Bach, Center on Organizational Innovation, Columbia University and David Stark, Center on Organizational Innovation, Columbia University

02-04: "Chains of Affection: The Structure of Adolescent Romantic and Sexual Networks," Peter Bearman, Institute for Social and Economic Research and Policy, Columbia University, James Moody, Sociology, Ohio State, Katherine Stovel, Sociology, University of Washington

02-05: "Permanently Beta: Responsive Organization in the Internet Era," Gina Neff, Center on Organizational Innovation (COI), Columbia University, and David Stark, Center on Organizational Innovation (COI), Columbia University

02-06: "Negotiating the End of Transition: A Network Approach to Political Discourse Dynamics, Hungary 1997,” Balázs Vedres, Columbia University, Péter Csigó, Ecole des Hautes Etudes en Sciences Sociales

02-07: "The Influence of Women and Racial Minorities Under Panel Decision-Making in the U.S. Court of Appeals," Sean Farhang, Political Science, Columbia University, Gregory Wawro, Political Science, Columbia University

02-08: "The Role of Effort Advantage in Consumer Response to Loyalty Programs: The Idiosyncratic Fit Heuristic" Ran Kivetz, Business, Columbia University, Itamar Simonson, Business, Stanford University

$\underline{2001}$

01-01: "Pathways of Property Transformation: Enterprise Network Careers in Hungary, 1988-2000 Outline of an Analytic Strategy," David Stark, Sociology, Columbia and Balázs Vedres, Sociology, Columbia

01-02: "Policy Space and Voting Coalitions in Congress: the Bearing of Policy on Politics, 1930-1954," Ira Katznelson, John Lapinski, and Rose Razaghian, Political Science, Columbia

01-03: "Doing Fractions: An Analysis of Partisan ship in Post-Socialist Russia," Andrew D. Buck, Sociology, Columbia

01-04: "Opposite-Sex Twins and Adolescent Same-Sex Attraction,” Peter Bearman, Sociology/ISERP and Hannah Brückner, Sociology, Yale

01-05: "On the Uneven Evolution of Human Know-How," Richard R. Nelson, Business/SIPA, Columbia 
01-06: "Self-Control for the Righteous: Toward a Theory of Luxury Pre-Commitment," Ran Kivetz, Business, Columbia and Itamar Simonson, Business, Stanford

01-07: "Distributing Intelligence and Organizing Diversity in New Media Projects," Monique Girard, ISERP, Columbia and David Stark, Sociology, Columbia

01-08: "Agricultural Biotechnology's Complementary Intellectual Assets," Gregory D. Graff, Agricultural and Resource Economics, Berkeley, Gordon C. Rausser, Agricultural Economics, Berkeley and Arthur A. Small, SIPA/Earth Institute, Columbia

For copies of ISERP Working Papers

Visit http://www.iserp.columbia.edu/research/working_papers/

write to iserp@columbia.edu or call 212-854-3081 
New York, NY 10027

Tel: 212-854-3081

Fax: 212-854-8925

Email: iserp@columbia.edu

www.iserp.columbia.edu

\section{EDITORIAL BOARD}

Karen Barkey, Sociology

Peter Bearman, Sociology/ISERP

Alan Brinkley, History

Alessandra Casella, Economics

Ester Fuchs, Political Science/SIPA

John Huber, Political Science

Ira Katznelson, Political Science/History

Herbert Klein, History

Mary Clare Lennon, Sociomedical Sciences

Mahmood Mamdani, Anthropology/SIPA

Marianthi Markatou, Biostatistics

William McAllister, ISERP

Kathryn Neckerman, ISERP

Richard Nelson, Business/SIPA

Elliott Sclar, Urban Planning/SIPA

Seymour Spilerman, Sociology

Charles Tilly, Sociology

Harrison White, Sociology

\section{ADMINISTRATION}

Peter Bearman, Director

Kathryn Neckerman, Associate Director Amira Ibrahim, Assistant Director 